\title{
Impact of Foliar-Applied Dormancy-Breaking Chemicals on Budburst and Metabolic Changes in Chemical Constituents of Leaves and Fruits of Malus sylvestris "Ein Shamer"
}

\author{
M. A. Seif El-Yazal \\ *Dept. of Agric. Botany, Fac. of Agric., Fayoum Univ., Egypt. \\ Correspondence: mas04@fayoum.edu.eg
}

Keywords: dormex, calcium nitrate, potassium nitrate, mineral oil, thiourea, bud break.

\begin{abstract}
This study was carried out during the two successive seasons of 2016 and 2017 to investigate the impact of dormex, dormex plus mineral oil, dormex plus potassium nitrate, dormex plus calcium nitrate and dormex plus thiourea on bud break, growth, yield and some chemical constituents of Malus sylvestris "Ein Shamer". The trees were grown in loamy sand soil, and sprayed with six treatments (dormex (4\%), (dormex (2\%) plus mineral oil $(2.5 \%)$, (dormex (2\%) plus potassium nitrate $(4 \%)$, (dormex $(2 \%)$ plus calcium nitrate $(4 \%)$ and (dormex $(2 \%)$ plus thiourea (1\%) and control. Generally, it was found that all studied growth parameters, date of flower bud break, percentage of bud break, fruit-setting, fruit weight, fruit size, fruit number/tree, yield/tree $(\mathrm{kg})$ and some chemical constituents of leaves (total chlorophyll, total carbohydrates, total protein, nitrogen, phosphorous and potassium contents) and some chemical constituents of fruits (total soluble solids(T.S.S.), T.S.S/ acid ratio, vitamin C, water content $\%$, total free amino acids, total carbohydrates, total sugars and reducing sugars) were increased with the application of the different treatments. The best results were obtained from the treatments of dormex at $4 \%$ followed by (dormex $(2 \%)$ plus mineral oil $(2.5 \%)$. On the contrary, the same treatments decreased total acidity and total phenols in fruits as compared to the control. It could be recommended to use dormex at $4 \%$ and (dormex (2\%) plus mineral oil (2.5\%) for improving bud break, growth, yield and chemical constituents of apple trees or fruits.
\end{abstract}

\section{Introduction}

The apple tree is a fruit-bearing deciduous temperate climate, which requires a certain amount of winter cold to overcome its lethargy, a physiological condition that occurs annually to survive cold winters $[1],[2],[3],[4],[5],[6],[7],[8]$.

However, it is difficult to determine the precise amount of cold that is required to get out of lethargy $[\mathbf{9}],[10],[11],[12],[13]$. This deficiency of cold affects a late sprouting in terminal buds, a poor and irregular flowering, large number of buds without sprouting, low fruit tie, low production and poor quality, as well as an increased risk of fire blight [15],[16]. A management strategy to reduce problems of insufficient cooling is the application of cold compensators.

Among the compensators mentioned in the literature and that have been applied are: calcium nitrate, potassium nitrate, mineral oil, thiourea, garlic extract, onion extract, dormex (hydrogenated cyanamide), aminoburts, semitrol, break trhu, Tecno Oil 100EW, calcium nitrate, revent, promalin, biozyme, thidiazuron (TDZ) and erger which widely used for stimulating bud break in various fruit species [14], [17],[18],[19],[20],[21],[22],[23],[24],[25].

The beneficial effect of dormex, , mineral oil, potassium nitrate, calcium nitrate and thiourea on bud break, growth, yield and some chemical constituents of different fruit species were studied by several workers $[1],[3],[4],[23],[24],[25],[26],[27],[28],[29]$.

\section{Materials and Methods}

The 12-year-old trees of (Malus sylvestris, Mill) "Ein Shamer" trees grafted on Malling-Merton 106 (MM 106) root stock were designated randomized, for a preliminary study in 2015/2016 and 
for the most analysis studies within the 2016/2017 and 2017/2018 seasons in an attempt to break dormancy. All trees were full-grown within the wood let (loamy sand soil) of the Horticultural Station at Aboksah in Abshawai, Fayoum, Egypt. Trees were selected in November, 2015 a uniform as possible for spray treatments.

\section{The experiment involved the following treatments}

1- Control (spraying with tap water)

2- Spraying with dormex at rate $4 \%$

3- Spraying with dormex at rate $2 \%$ plus mineral oil at rate $2.5 \%$

4- Spraying with dormex at rate $2 \%$ plus potassium nitrate at rate $4 \%$

5 - Spraying with dormex at rate $2 \%$ plus calcium nitrate at rate $4 \%$

6- Spraying with dormex at rate $2 \%$ plus thiourea at rate $1 \%$

The physical and chemical characters of the orchard soil was determined according to [30] and the results are shown in Table (1).

Table 1. Chemical and physical analysis of the soil

\begin{tabular}{|c|c|c|c|c|c|c|c|c|c|c|}
\hline & \multicolumn{10}{|c|}{ Physical characteristics } \\
\hline \multirow[t]{2}{*}{ Depth } & \multicolumn{4}{|c|}{ Particle size distribution } & \multirow[t]{2}{*}{ Texture } & \multirow{2}{*}{$\begin{array}{l}\text { Bulk } \\
\text { density } \\
\mathrm{g} / \mathrm{cm}^{3}\end{array}$} & \multirow{2}{*}{$\begin{array}{c}\text { Organic } \\
\text { mater } \\
\%\end{array}$} & \multicolumn{3}{|c|}{$\begin{array}{l}\text { Soil moisture } \\
\text { constant } \%\end{array}$} \\
\hline & $\begin{array}{l}\text { Coarse } \\
\text { sand } \%\end{array}$ & $\begin{array}{l}\text { Fine } \\
\text { sand } \%\end{array}$ & $\begin{array}{c}\text { Silt } \\
\%\end{array}$ & $\begin{array}{c}\text { Clay } \\
\%\end{array}$ & & & & F. C & W.P & A.W \\
\hline $0-30$ & 50.13 & 29.50 & 9.02 & 11.35 & \multirow[t]{2}{*}{$\begin{array}{l}\text { Loamy } \\
\text { Sand }\end{array}$} & 1.43 & 0.71 & 19.2 & 7.12 & 11.22 \\
\hline $30-60$ & 50.95 & 26.17 & 8.35 & 14.53 & & 1.46 & 0.76 & 19.1 & 7.94 & 12.33 \\
\hline \multicolumn{11}{|c|}{ chemical characteristics } \\
\hline & \multicolumn{4}{|c|}{ Soluble cations (meq /L) } & $\mathrm{pH}$ & $\mathrm{ECe}$ & \multicolumn{4}{|c|}{ Soluble anions (meq/l) } \\
\hline & $\mathrm{Ca}^{++}$ & $\mathrm{Mg}^{++}$ & $\mathrm{Na}^{+}$ & $\mathrm{K}^{+}$ & & & $\mathrm{Cl}^{-}$ & $\mathrm{HCO}_{3}^{-}$ & & $\mathrm{O}_{4}^{--}$ \\
\hline $0-30$ & 15.33 & 17.25 & 13.10 & 1.54 & 7.34 & 3.50 & 6.15 & 3.01 & & 5.69 \\
\hline $30-60$ & 12.15 & 14.20 & 7.12 & 089 & 7.56 & 3.10 & 4.20 & 3.12 & & 1.58 \\
\hline
\end{tabular}

In all experiments, Phosphorous as calcium super phosphate $\left(15.5 \% \mathrm{P}_{2} \mathrm{O}_{5}\right)$ at the rate of $200 \mathrm{~kg} / \mathrm{fed}$., was added in the orchard in the second week of February. Nitrogen as ammonium nitrate $(33.5 \% \mathrm{~N})$ at the rate of $250 \mathrm{~kg} / \mathrm{fed}$. was added in two doses for the orchard (first dose $150 \mathrm{~kg} / \mathrm{fed}$. in the second week of February and second dose $100 \mathrm{~kg} / \mathrm{fed}$. before top flowering (first week of April) and potassium sulphate $\left(48 \% \mathrm{~K}_{2} \mathrm{O}\right)$ at the rate of $50 \mathrm{~kg} / \mathrm{fed}$., was given in two equal doses in alternative with nitrogen fertilizer. The first dose of fertilizer was added in March and the second dose given after 30 days from the first one. The other cultural practices were followed as normal. The control trees were sprayed with tap water, however, dormex, calcium nitrate, potassium nitrate, mineral oil and thiourea were sprayed before the end of dormancy (nearly $30^{\text {th }}$ of December), with a volume of $4 \mathrm{~L} /$ tree for each one. Triton $\mathrm{B}$ as a wetting agent at $0.1 \%$ was added to the spraying solutions.

\section{Data recorded}

\section{A. Morphological characteristics}

In both the two successive seasons, bud counts were made for each tree. The dates on which flower and vegetative bud started to open were recorded. Number of vegetative and flower buds 
was counted when all buds were opened and the percentages were estimated. The dormant buds were also counted and were expressed as percentage from the total number of buds. The dates at which flowering reached $25,50,75$ and 100 percent of the total flowers were estimated in each treatment. Flowers whose calyx began to extend were tagged in order to determine the percent of fruit set. The yield of fruits in $\mathrm{kg} / \mathrm{tree}$ as well as the number of mature fruits/tree were recorded when fruits reached the commercial colour to be picked.

In order to determine fruit quality, 20 fruits were taken at random from each tree as a sample. Samples were transferred immediately to the laboratory. Each fruit was weighed to get the average fruit weight. Average fruit size was determined by emerging the fruit in a jar containing water and receiving the excess water in a graduated cylinder.

\section{Chemical analysis}

Fresh and dried leaves as well as fruits (May15 $5^{\text {th }}$ for chemical constituents \& $30^{\text {th }}$ July for mineral elements in leaves and at harvesting, for fruits) were taken to determine the following constituents: total chlorophyll was extracted from fresh leaves by acetone $(80 \%)$ and its concentration was determined as $\mathrm{mg} / 100 \mathrm{~g}$ fresh weight according to[31], total carbohydrates $\mathrm{mg} / \mathrm{g}$ dry weight were determined colorimetrically by using phenol-sulphuric acid reagent according to the method described by [32]. Total free amino acids in fresh fruits were determined as $\mathrm{mg} / \mathrm{g}$ fresh weight colorimetrically using ninhydrin reagent according to the method described by [33]. (Total and reducing sugars were determined as $\mathrm{mg} / \mathrm{g}$ fresh weight using phosphomolybdic acid reagent., total phenols in fresh fruits were determined as $\mathrm{mg} / \mathrm{g}$ fresh weight using Folin-Denis reagent. Water content in fruits was determined, total soluble solids (T.S.S.) in fruits were estimated using handle Refractometer model PZONr. 19877, total acidity was estimated in fruits as malic acids using sodium hydroxide for a known normality and phenolphthaline as an indicator. Total soluble solids/ acid ratio were calculated and vitamin $\mathrm{C}$ content in fruits, Nitrogen $\%$, crude protein percentage and phosphorus \% in dry leaves were determined according to [34]. Potassium was determined by Flame Photometer, Parkin-Elmer model 52 according to the method described by [35].

\section{Statistical analysis:}

The experiment was in a complete randomized block design with 6 treatments and 3 replicates for each treatment. One tree was used as a replicate. Results were statistically analyzed using the L.S.D. at probability level of 5\% for comparisons according to [36].

\section{Results}

\section{A - Date of flower bud break:}

Data presented in Table (2) clearly indicated that spraying apple trees with all the tested substances hastened the beginning of flower bud break as compared to the control. This earliness reached about 32 and 31 days for dormex at 4\%, 32 and 32 days for dormex at $2 \%+$ mineral oil at $2.5 \%, 31$ and 31 days for dormex at $2 \%+$ potassium nitrate at $4 \%, 32$ and 33 days for dormex at $2 \%+$ calcium nitrate at $4 \%$ and 32 and 32 days for dormex at $2 \%+$ thiourea at $1 \%$ over the control in both seasons, respectively.

As regards to the effect of the tested substances on $50 \%$ bud break, the present results clearly show that all treatments hastened $50 \%$ bud break as compared to the control. This earliness reached about 28 and 30 days for dormex at 4\%, 28 and 29 days for dormex at $2 \%+$ mineral oil at $2.5 \%, 24$ and 27 days for dormex at $2 \%+$ potassium nitrate at $4 \%, 22$ and 27 days for dormex at $2 \%+$ calcium nitrate at $4 \%$ and 23 and 25 days for dormex at $2 \%+$ thiourea at $1 \%$ over the control in both seasons, respectively. 
Table 2. Effect of Spraying with dormex, dormex plus mineral oil, dormex plus potassium nitrate, dormex plus calcium nitrate and dormex plus thiourea treatments on time of flower bud opening in

"Ein Shamer" apple trees

\begin{tabular}{|c|c|c|c|c|c|c|c|c|c|c|c|c|}
\hline \multirow{3}{*}{ Treatments } & \multicolumn{12}{|c|}{ Date of flower bud opening } \\
\hline & \multicolumn{2}{|c|}{ Beginning } & \multicolumn{2}{|c|}{$25 \%$} & \multicolumn{2}{|c|}{$50 \%$} & \multicolumn{2}{|c|}{$75 \%$} & \multicolumn{2}{|c|}{ End } & \multicolumn{2}{|c|}{$\begin{array}{l}\text { Flowering } \\
\text { period (No. } \\
\text { of days) }\end{array}$} \\
\hline & 2016 & 2017 & 2016 & 2017 & 2016 & 2017 & 2016 & 2017 & 2016 & 2017 & 2016 & 2017 \\
\hline Control & $22 / 2$ & $23 / 2$ & $25 / 2$ & $28 / 2$ & $2 / 3$ & $3 / 3$ & $14 / 3$ & $11 / 3$ & $28 / 3$ & $26 / 3$ & 34 & 29 \\
\hline Dormex $4 \%$ & $21 / 1$ & $20 / 1$ & $24 / 1$ & $30 / 1$ & $2 / 2$ & $1 / 2$ & $15 / 2$ & $17 / 2$ & $16 / 2$ & $19 / 2$ & 26 & 26 \\
\hline $\begin{array}{l}\text { Dormex } 2 \% \\
+ \text { Mineral oil } 2 . \\
5 \%\end{array}$ & $21 / 1$ & $21 / 1$ & $25 / 1$ & $31 / 1$ & $3 / 2$ & $2 / 2$ & $14 / 2$ & $19 / 2$ & $18 / 2$ & $20 / 2$ & 28 & 30 \\
\hline $\begin{array}{l}\text { Dormex } 2 \% \\
+ \text { Potassium } \\
\text { nitrate } 4 \%\end{array}$ & $22 / 1$ & $23 / 1$ & $26 / 1$ & $2 / 2$ & $6 / 2$ & $4 / 2$ & $18 / 2$ & $20 / 2$ & $20 / 2$ & $25 / 2$ & 29 & 33 \\
\hline $\begin{array}{l}\text { Dormex } 2 \% \\
+ \text { Calcium } \\
\text { nitrate } 4 \%\end{array}$ & $21 / 1$ & $21 / 1$ & $26 / 1$ & $6 / 2$ & $8 / 2$ & $4 / 2$ & $19 / 2$ & $20 / 2$ & $24 / 2$ & $26 / 2$ & 34 & 36 \\
\hline $\begin{array}{l}\text { Dormex } 2 \% \\
+ \text { Thiourea } 1 \%\end{array}$ & $21 / 1$ & $22 / 1$ & $27 / 1$ & $5 / 2$ & $7 / 2$ & $6 / 2$ & $17 / 2$ & $21 / 2$ & $25 / 2$ & $28 / 2$ & 35 & 37 \\
\hline
\end{tabular}

\section{B-Percentage of bud break:}

Data presented in Table (3) clearly show that all treatments gave a high percentage of flower bud break compared with the control. The maximum increases were recorded with dormex $4 \%$ which recorded 89.11 and $88.24 \%$ in both seasons as compared with the control, respectively.

\section{C- Yields and its components:}

Data in Table (3) indicated that all the tested substances increased apple yield and its components (fruit-setting, fruit weight, fruit size and fruit number) as compared to the control trees. Such trend was true during the two studied seasons. The maximum increases were recorded with dormex at 4\% which recorded 21.90 and 18.66 for fruit-setting, 56.03 and $38.08 \%$ for fruit weight, 30.54 and $28.04 \%$ for fruit size, 56.81 and $50.19 \%$ for fruit number and 62.06 and $38.32 \%$ for apple yield/tree in both seasons, respectively over the control trees. 
Table 3. Effect of dormex, dormex plus mineral oil, dormex plus potassium nitrate, dormex plus calcium nitrate and dormex plus thiourea treatments on the percentage of bud break, fruit setting, fruit weight $(\mathrm{gm})$, fruit size $\left(\mathrm{CC}^{3}\right)$, total number of fruits/tree and yield/tree in

"Ein Shamer" apple trees

\begin{tabular}{|c|c|c|c|c|c|c|c|c|c|c|c|c|}
\hline \multirow[t]{2}{*}{ Treatments } & \multicolumn{2}{|c|}{$\begin{array}{c}\text { Bud } \\
\text { break \% }\end{array}$} & \multicolumn{2}{|c|}{ Fruit set\% } & \multicolumn{2}{|c|}{$\begin{array}{l}\text { Fruit weight } \\
\text { (gm) }\end{array}$} & \multicolumn{2}{|c|}{$\begin{array}{c}\text { Fruit size } \\
\left(\mathbf{C} \mathbf{C}^{3}\right)\end{array}$} & \multicolumn{2}{|c|}{$\begin{array}{l}\text { Total number } \\
\text { of fruits / tree }\end{array}$} & \multicolumn{2}{|c|}{$\begin{array}{l}\text { Yield per } \\
\text { tree (Kg) }\end{array}$} \\
\hline & 2016 & 2017 & 2016 & 2017 & 2016 & 2017 & 2016 & 2017 & 2016 & 2017 & 2016 & 2017 \\
\hline Control & 73.1 & 74.36 & 12.1 & 13.18 & 80.63 & 82.28 & 92.00 & 93.64 & 110.00 & 113.58 & 12.31 & 13.15 \\
\hline Dormex 4\% & 89.11 & 88.24 & 18.88 & 18.20 & 121.62 & 122.73 & 120.10 & 119.90 & 172.50 & 170.59 & 19.95 & 18.19 \\
\hline $\begin{array}{l}\text { Dormex } 2 \% \\
+ \text { Mineral oil } \\
2.5 \%\end{array}$ & 88.55 & 88.01 & 18.15 & 17.85 & 112.16 & 113.15 & 114.10 & 115.00 & 160.00 & 161.85 & 17.90 & 17.56 \\
\hline $\begin{array}{l}\text { Dormex } 2 \% \\
+ \text { Potassium } \\
\text { nitrate } 4 \%\end{array}$ & 87.90 & 87.11 & 18.34 & 18.11 & 116.19 & 112.60 & 116.00 & 115.11 & 160.00 & 162.20 & 17.00 & 17.20 \\
\hline $\begin{array}{l}\text { Dormex } 2 \% \\
+ \text { Calcium } \\
\text { nitrate } 4 \%\end{array}$ & 89.00 & 88.03 & 17.90 & 17.60 & 112.70 & 114.70 & 113.10 & 114.62 & 155.20 & 151.72 & 16.11 & 16.55 \\
\hline $\begin{array}{l}\text { Dormex } 2 \% \\
+ \text { Thiourea } \\
1 \%\end{array}$ & 82.15 & 80.90 & 15.30 & 15.60 & 109.60 & 109.80 & 111.21 & 110.10 & 140.20 & 145.15 & 10.95 & 11.93 \\
\hline $\begin{array}{l}\text { L.S.D at } \\
5 \%\end{array}$ & 2.01 & 2.20 & 1.21 & 1.17 & 1.12 & 1.16 & 1.22 & 1.23 & 2.60 & 2.55 & 1.02 & 1.01 \\
\hline
\end{tabular}

\section{D - Chemical constituents of leaves:}

\section{1- Total chlorophyll, total carbohydrates and total protein}

Data presented in Table (4) clearly showed that, during the two successive seasons of the study, all treatments increased the concentrations of leaf constituents (total chlorophyll, total carbohydrates, and total protein) as compared to the control. The best results were observed when apple trees were sprayed with dormex at $4 \%$ which recorded 10.28 and $9.55 \%$ for total chlorophyll, 19.26 and $15.53 \%$ for total carbohydrates and 24.56 and $14.77 \%$ for total protein in both seasons over the control plants, respectively.

\section{2- Nitrogen, phosphorus and potassium concentrations in leaves:}

Data presented in Table (4) revealed that, leaves of apple trees contained higher concentrations of nitrogen, phosphorus and potassium under foliar spray with any of the treatments than the control. The maximum increases were obtained when dormex at 4\% were used which recorded 24.56 and $14.77 \%$ for nitrogen, 30.00 and $25.00 \%$ for phosphorous and 3.33 and 1.31 for potassium in both seasons respectively over the control trees. 
Table 4. Effect of dormex, dormex plus mineral oil, dormex plus potassium nitrate, dormex plus calcium nitrate and dormex plus thiourea treatments on chemical contents of leaves in "Ein

Shamer" variety

\begin{tabular}{|c|c|c|c|c|c|c|c|c|c|c|c|c|}
\hline \multirow[t]{2}{*}{ Treatments } & \multicolumn{2}{|c|}{$\begin{array}{c}\text { Total } \\
\text { chlorophyll } \\
\text { mg/g.f.w }\end{array}$} & \multicolumn{2}{|c|}{$\begin{array}{c}\text { Total } \\
\text { carbohydrate } \\
\text { mg/g.d.w }\end{array}$} & \multicolumn{2}{|c|}{$\begin{array}{c}\text { Total } \\
\text { protein } \\
\%\end{array}$} & \multicolumn{2}{|c|}{ N \% } & \multicolumn{2}{|c|}{ Р \% } & \multicolumn{2}{|c|}{ K \% } \\
\hline & 2016 & 2017 & 2016 & 2017 & 2016 & 2017 & 2016 & 2017 & 2016 & 2017 & 2016 & 2017 \\
\hline Control & 1.75 & 1.78 & 74.29 & 77.13 & 9.68 & 10.56 & 1.55 & 1.69 & 0.20 & 0.20 & 1.50 & 1.52 \\
\hline Dormex 4\% & 1.96 & 1.95 & 88.60 & 89.11 & 12.06 & 12.12 & 1.93 & 1.94 & 0.26 & 0.25 & 1.55 & 1.54 \\
\hline $\begin{array}{l}\text { Dormex } 2 \% \\
+ \text {-Mineral oil } \\
2.5 \%\end{array}$ & 1.92 & 1.90 & 83.91 & 84.52 & 11.89 & 11.80 & 1.90 & 1.87 & 0.24 & 0.23 & 1.52 & 1.53 \\
\hline $\begin{array}{l}\text { Dormex } 2 \% \\
+ \text { Potassium } \\
\text { nitrate } 4 \%\end{array}$ & 1.90 & 1.91 & 83.72 & 82.15 & 11.55 & 11.41 & 1.88 & 1.85 & 0.22 & 0.22 & 1.52 & 1.52 \\
\hline $\begin{array}{l}\text { Dormex } 2 \% \\
+ \text { Calcium } \\
\text { nitrate } 4 \%\end{array}$ & 1.86 & 1.88 & 82.98 & 80.32 & 11.11 & 11.18 & 1.80 & 1.83 & 0.20 & 0.21 & 1.51 & 1.52 \\
\hline $\begin{array}{l}\text { Dormex } 2 \% \\
+ \text { Thiourea } \\
1 \%\end{array}$ & 1.80 & 1.82 & 81.12 & 81.19 & 11.01 & 10.95 & 1.76 & 1.74 & 0.21 & 0.23 & 1.49 & 1.50 \\
\hline L.S.D at $5 \%$ & 0.05 & 0.04 & 1.18 & 1.20 & 0.22 & 0.26 & 0.04 & 0.03 & 0.01 & 0.01 & N.S & N.S \\
\hline
\end{tabular}

\section{E - Chemical constituents of fruits:}

Data of Tables (5 and 6) clearly showed that spraying apple trees with any of the tested substances significantly improved the chemical constituents of fruits (total soluble solids (T.S.S.), total acidity, T.S.S/ acid ratio, vitamin C, water content \%, total free amino acids, total carbohydrates, total sugars, reducing sugars, total phenols) as compared to the control trees. Such trend was true during the two seasons of the study. The maximum increases were recorded with dormex at $4 \%$ which recorded 26.64 and $28.57 \%$ for total soluble solids, 72.15 and $83.48 \%$ for T.S.S/ acid ratio, 31.30 and $78.07 \%$ for vitamin C, 7.97 and $8.01 \%$ for water content, 19.49 and $10.00 \%$ for total carbohydrates, 22.71 and $19.61 \%$ for total sugars, 30.09 and $33.27 \%$ for reducing sugars and 28.00 and $21.46 \%$ for total free amino acids in both seasons respectively, as compared to the control trees. On the other hand, the data in Table (5) also showed a marked decrease in total acidity and total phenols concentrations in fruits when trees were treated with any of the tested substances comparing with the control trees. 
Table 5. Effect dormex, dormex plus mineral oil, dormex plus potassium nitrate, dormex plus calcium nitrate and dormex plus thiourea treatments on chemical fruit quality of "Ein Shamer" apple fruits

\begin{tabular}{|l|c|c|c|c|c|c|c|c|}
\hline \multirow{2}{*}{ Treatments } & \multicolumn{2}{|c|}{ TSS \% } & \multicolumn{2}{c|}{ Acidity \% } & \multicolumn{2}{c|}{$\begin{array}{c}\text { TSS/Acidity } \\
\text { ratio }\end{array}$} & \multicolumn{2}{c|}{$\begin{array}{c}\text { Vitamin C } \\
\text { mg/100 ml } \\
\text { juice }\end{array}$} \\
\cline { 2 - 9 } & $\mathbf{2 0 1 6}$ & $\mathbf{2 0 1 7}$ & $\mathbf{2 0 1 6}$ & $\mathbf{2 0 1 7}$ & $\mathbf{2 0 1 6}$ & $\mathbf{2 0 1 7}$ & $\mathbf{2 0 1 6}$ & $\mathbf{2 0 1 7}$ \\
\hline Control & 10.36 & 10.50 & 1.06 & 1.07 & 9.77 & 9.81 & 1.15 & 1.14 \\
\hline Dormex 4\% & 13.12 & 13.50 & 0.78 & 0.75 & 16.82 & 18.00 & 1.51 & 1.52 \\
\hline $\begin{array}{l}\text { Dormex2\% } \\
\text { +Mineral oil 2. 5\% }\end{array}$ & 12.95 & 12.98 & 0.85 & 0.82 & 15.23 & 15.82 & 1.50 & 1.49 \\
\hline $\begin{array}{l}\text { Dormex 2\% } \\
\text { +Potassium nitrate 4\% }\end{array}$ & 12.84 & 12.86 & 0.86 & 0.84 & 14.93 & 15.30 & 1.48 & 1.48 \\
\hline $\begin{array}{l}\text { Dormex 2\% } \\
+ \text { Calcium nitrate 4\% }\end{array}$ & 12.20 & 12.33 & 0.89 & 0.88 & 13.70 & 14.01 & 1.45 & 1.46 \\
\hline $\begin{array}{l}\text { Dormex 2\% } \\
\text { +Thiourea 1\% }\end{array}$ & 12.10 & 12.16 & 0.89 & 0.90 & 13.59 & 13.51 & 1.40 & 1.41 \\
\hline L.S.D at 5\% & 0.04 & 0.03 & 0.06 & 0.04 & 0.95 & 0.93 & N.S & N.S \\
\hline
\end{tabular}

Table 6. Effect of dormex, dormex plus mineral oil, dormex plus potassium nitrate, dormex plus calcium nitrate and dormex plus thiourea treatments on some chemical composition of "Ein Shamer" apple fruits

\begin{tabular}{|l|c|c|c|c|c|c|c|c|c|c|c|c|}
\hline \multirow{2}{*}{ Treatments } & \multicolumn{2}{|c|}{$\begin{array}{c}\text { Water } \\
\text { content \% }\end{array}$} & \multicolumn{2}{c|}{$\begin{array}{c}\text { Total } \\
\text { carbohydrates } \\
\text { mg/F.W }\end{array}$} & \multicolumn{2}{c|}{$\begin{array}{c}\text { Total sugars } \\
\text { mg/g F.W }\end{array}$} & \multicolumn{2}{c|}{$\begin{array}{c}\text { Reducing } \\
\text { sugars mg/g } \\
\text { F.W }\end{array}$} & \multicolumn{2}{c|}{$\begin{array}{c}\text { Total free } \\
\text { amino acids } \\
\text { mg/g F.W }\end{array}$} & \multicolumn{2}{c|}{$\begin{array}{c}\text { Total } \\
\text { phenols } \\
\text { mg/g F.W }\end{array}$} \\
\cline { 2 - 14 } & $\mathbf{2 0 1 6}$ & $\mathbf{2 0 1 7}$ & $\mathbf{2 0 1 6}$ & $\mathbf{2 0 1 7}$ & $\mathbf{2 0 1 6}$ & $\mathbf{2 0 1 7}$ & $\mathbf{2 0 1 6}$ & $\mathbf{2 0 1 7}$ & $\mathbf{2 0 1 6}$ & $\mathbf{2 0 1 7}$ & $\mathbf{2 0 1 6}$ & $\mathbf{2 0 1 7}$ \\
\hline Control & 75.20 & 76.10 & 139.50 & 142.55 & 83.61 & 84.10 & 53.50 & 54.10 & 1.75 & 1.77 & 0.48 & 0.51 \\
\hline Dormex 4\% & 81.20 & 82.20 & 166.7 & 169.00 & 102.60 & 100.60 & 69.60 & 72.10 & 2.24 & 2.15 & 0.26 & 0.27 \\
\hline $\begin{array}{l}\text { Dormex2\% } \\
\text { +Mineral oil } \\
\text { 2.5\% }\end{array}$ & 79.00 & 78.54 & 164.10 & 166.50 & 100.32 & 98.15 & 67.60 & 68.16 & 2.21 & 2.19 & 0.39 & 0.37 \\
\hline $\begin{array}{l}\text { Dormex 2\% } \\
\text { +Potassium } \\
\text { nitrate 4\% }\end{array}$ & 78.25 & 78.66 & 160.15 & 160.20 & 98.20 & 96.10 & 65.25 & 64.25 & 2.10 & 2.15 & 0.36 & 0.39 \\
\hline $\begin{array}{l}\text { Dormex 2\% } \\
\text { +Calcium } \\
\text { nitrate 4\% }\end{array}$ & 78.19 & 79.32 & 154.30 & 156.10 & 95.50 & 94.10 & 63.10 & 61.20 & 1.90 & 1.95 & 0.42 & 0.45 \\
\hline $\begin{array}{l}\text { Dormex 2\% } \\
\text { +Thiourea } \\
\text { 1\% }\end{array}$ & 76.15 & 77.45 & 150.90 & 149.10 & 92.10 & 90.90 & 61.10 & 59.15 & 1.90 & 1.92 & 0.40 & 0.41 \\
\hline $\begin{array}{l}\text { L.S.D at } \\
\text { 5\% }\end{array}$ & 1.19 & 1.13 & 2.74 & 2.65 & 1.01 & 1.02 & 1.18 & 1.15 & 0.06 & 0.09 & 0.03 & 0.05 \\
\hline
\end{tabular}

\section{Discussion}

Spraying apple trees with any of the tested treatments (dormex 4\%, dormex $2 \%$ plus mineral oil $2.5 \%$, dormex $2 \%$ plus potassium nitrate $4 \%$, dormex $2 \%$ plus calcium nitrate $4 \%$ and dormex $2 \%$ plus thiourea $1 \%$ ) resulted in vigorous plant (tree) growth as well as high productivity with good fruit quality. Treatments increased the measured growth characters. This was due to the fact that 
these treatments resulted in more availability of macronutrients $(\mathrm{N}, \mathrm{K}$ and $\mathrm{Ca})$ to plants. Enhancement of growth parameters with $\mathrm{N}$ application would be expected since nitrogen is of extreme importance to plants. It is a constituent of many important substances within plant cells such as protoplasm, in addition to amino acids, nucleic acids, protein and chlorophylls [37]. The high levels of endogenous auxin and gibberellins were found in those plants sprayed with high $\mathrm{N}$ fertilizer [38], which encourage cell division and cell elongation, increases leaf number and produce a sufficient assimilation area for maximum rate of photosynthesis [39]. Moreover, [40] reported that, the role of $\mathrm{K}$ in metabolism, growth and yield formation can be characterized by two major function: as an activator of enzymes and as $\mathrm{K}^{-}$ions are very mobile within the plant as well as within a cell are transported through biological membranes with high rate and specificity. More than 60 enzymes are known to require $\mathrm{K}^{+}$as an activator. The high mobility of $\mathrm{K}^{+}$on photosynthesis phloem loading and phloem transport etc. Such important physiological roles enable potassium to perform its functions, which lead to an increase in various vegetative growth and yield. Moreover, the effect of hydrogen cyanamide and other substances used on nitrogen and protein content, it is clear from the present data that, buds of apple trees contained higher concentrations of total nitrogen under foliar spray with any of the treatments than the control. These findings agreed with the suggestion of [41],[42], They concluded that cyanide ion may play a role in inducing enzyme activity, promoting the translocation of stored reserves and the uptake of nitrogen with water for leading to bud break. Moreover,[43] indicated that hydrogen cyanamide is directly involved in nitrogen metabolism and the production of protein. The degradation of cyanamide was demonstrated to occur through urea to other compounds and both are utilized in production of amino acids. Also, [44] found that hydrogen cyanamide penetrate the bud scals, gets absorbed in the buds and initiates the processes leading to bud break. It is rapidly metabolized in the plant and helps in the synthesis of amino acids. Also, the favorable effect of the used substances on date of flower bud opening may be due to their stimulation effect of natural gibberellin. In this connection $[45],[46]$, concluded that the induction of flowering could be correlated with a natural rise in gibberellin which promote flower formation in plants by either facilitating the formation of flowering hormone in the leaves or expressing it in the growing buds. Gibberellins also may be a primarily responsible for bolting which may be essential for the formation of the floral stimulus in leaves. Moreover, [46],[47] reported that some different spray treatments may break dormancy by decreasing ABA content in buds.

The improving effect of dormex $4 \%$, dormex $2 \%$ plus mineral oil $2.5 \%$, dormex $2 \%$ plus potassium nitrate $4 \%$, dormex $2 \%$ plus calcium nitrate $4 \%$ and dormex $2 \%$ plus thiourea $1 \%$ on yield and its components was mainly attributed to its positive action on enhancing growth parameters (Table 2) and photosynthetic pigments of plant leaves (Table 4). In this respect, [48] reported that when a bud opens and attains the shape of a shoot, its tip acts as a strong sink for metabolites and thus being interception center for photosynthates and nutrients results in earlier start of the bloom. The promotive effect of dormex $4 \%$, dormex $2 \%$ plus mineral oil $2.5 \%$, dormex $2 \%$ plus potassium nitrate $4 \%$, dormex $2 \%$ plus calcium nitrate $4 \%$ and dormex $2 \%$ plus thiourea $1 \%$ on chlorophyll formation might be attributed to their enhancing effect on the nutritional status of apple trees. Also the increase of total chlorophyll by spraying with $\mathrm{N}$ and $\mathrm{K}$ may be due to that $\mathrm{N}$ and $\mathrm{K}$ play an important role for stimulating chlorophyll synthesis enzymes which can be reflected on the formation of chlorophyll molecule. Moreover, the stimulating effect of dormex 4\%, dormex 2\% plus mineral oil $2.5 \%$, dormex $2 \%$ plus potassium nitrate $4 \%$, dormex $2 \%$ plus calcium nitrate $4 \%$ and dormex $2 \%$ plus thiourea $1 \%$ as foliar spray on total carbohydrates concentrations in leaves of sprayed trees may be directly or indirectly due to certain enzymes which activate the anabolic processes leading to the accumulation of these substances. The increase of all mentioned constituents by foliar $\mathrm{N}$ application may be due to that certain enzymes may be activated as a result of these treatments leading to the accumulation of such substances. The increase of macronutrients $(\mathrm{N}, \mathrm{P}$, and $\mathrm{K})$ and protein content were supported by the results of [26] on apple trees. In this connection [49] found that there was a decrease in the nitrogen concentration of the woody tissues in the spring, particularly in the bark tissues of shoots. This might be attributed to the movement of 
nitrogenous compounds from the bark and wood to the developing flower buds and growing points. Moreover, the stimulating effect of dormex $4 \%$, dormex $2 \%$ plus mineral oil $2.5 \%$, dormex $2 \%$ plus potassium nitrate $4 \%$, dormex $2 \%$ plus calcium nitrate $4 \%$ and dormex $2 \%$ plus thiourea $1 \%$ on physical characters (fruit weight and size) and chemical fruit characters (T.S.S, total acidity, vitamin $\mathrm{C}$, total carbohydrates, total sugars, reducing sugars, total free amino acids and total phenols) was mainly attributed to its positive action on enhancing growth parameters (Table 2) and photosynthetic pigments of plant leaves (Table 4). Concerning the effect on T.S.S. and acidity in fruits, the results showed that all treatments increased T.S.S. significantly and decreased the total acidity. This increase in T.S.S. may be due to the increase in synthesis of carbohydrates and its accumulation in the developing fruits of the treated trees. In this connection, [50] mentioned that sugars represented about $70 \%$ of the total soluble solids (T.S.S) in apple fruits and the increase in sugars lead to increase in T.S.S. He also added that the increase in cellular sap lead to decrease in acidity as a result of dilution of the organic acids. Moreover [51],[52] on pear, found that the increase in T.S.S. may be due to rapid conversion of starch, and the decrease in total acids content with advancement of ripening period may be due to that the acids are converted into soluble solids. The increase in vitamin $\mathrm{C}$ may be due to that fruits synthesize ascorbic acid from hexose sugars and hence the adequate supply of these precursors would greatly depend on the photosynthetic activity [53]. In this connection [54] suggested that water and nutrients may also be mobilized to the growing points at the expense of the developing fruits. Also,[55] found that large "Anna" apple fruits had significantly higher reducing and total sugars as well as lower starch and non-reducing sugars than small sized fruits. Moreover,[51] found that the increase in accumulation of T.S.S. and sugars during maturation has been related to accumulation of glucose, sucrose and higher levels of fructose in "Bartlett" pear. On the other hand,[52] found that the total phenols content (as tannic acid) decrease during ripening period. The reduction in phenolic content during ripening process may be attributed to its hydrolysis to different components such as sugars, acids and other compounds [56].

\section{Conclusions}

From the results of the present investigation, it could be concluded that the application of dormex $4 \%$, dormex $2 \%$ plus mineral oil $2.5 \%$, dormex $2 \%$ plus potassium nitrate $4 \%$, dormex $2 \%$ plus calcium nitrate $4 \%$ and dormex $2 \%$ plus thiourea $\%$ greatly increased growth and apple yield as well as improved apple quality and its chemical constituents. The constituents of these substances participate in the different metabolic processes which increased syntheses of chlorophyll, carbohydrates, total free amino acids, and absorption of essential nutrients, so that the use of dormex $4 \%$, dormex $2 \%$ plus mineral oil $2.5 \%$, dormex $2 \%$ plus potassium nitrate $4 \%$, dormex $2 \%$ plus calcium nitrate $4 \%$ and dormex $2 \%$ plus thiourea $1 \%$ could increase apple productivity with high fruit quality.

\section{Conflict of Interest}

The author declares no conflict of interest.

\section{References}

[1] J. L. Y. Petri and G.B. Leite, Budbreak induction in apple tres by erger and calcium nitrate application, Acta Horticulturae. 884(65) (2010) 511-516.

[2] [M.A. Seif El-Yazal and M.M. Rady, Foliar-applied Dormex ${ }^{\mathrm{TM}}$ or thiourea-enhanced proline and biogenic amine contents and hastened breaking bud dormancy in "Ain Shemer" apple trees, Trees. 27 (1) (2013) 161-169. 
[3] M.A. Seif El-Yazal et al., Foliar-applied dormancy-breaking chemicals change the content of nitrogenous compounds in the buds of apple (Malus sylvestris Mill. cv. Anna) trees, Journal of Horticultural Science \& Biotechnology87(4) (2012) 299-304.

[4] M.A. Seif El-Yazal et al., Exogenous dormancy-breaking substances positively change endogenous phytohormones and amino acids during dormancy release in 'Anna' apple trees, Plant Growth Regul. 72(2014) 211-220.

[5] M.A.Seif El-Yazal, Effect of timing of mineral oil spraying on budburst and metabolic changes in "Barkhar" apple trees under conditions of inadequate winter chilling in Egypt, Horticult. Int. J. 3(2) (2019a) 67-75. DOI:10.15406/hij.2019.03.00114

[6] M.A.Seif El-Yazal, Seasonal changes in soluble and non-soluble carbohydrates during and after dormancy release in early and late varieties of apple (Malus Sylvestris, Mill) trees, International Journal For Empirical Education and Research. 3(20) (2019b)1-18.

[7] M.A.Seif El-Yazal, Impact of chilling requirement on budburst, floral development and hormonal level in buds of early and late apple varieties (Malus sylvestris, Mill) under natural conditions, Journal of Horticulture and Plant Research. 8(2019c)1-11.

[8] M.A.Seif El-Yazal, Impact of Chilling Requirements on Metabolic Changes in Phenolic Compounds in Buds during and after Dormancy Releasing in early and late (Malussylvestris, Mill) Apple Varieties, International Letters of Natural Sciences. 81(2021) 13-22.

[9] M.E. Carvajal et al., Caracterización calorimétrica de la brotación de yemas florales de manzano, Agrociencia. 34(5) (2000) 543-551.

[10] M.A. Seif El-Yazal et al., Foliar-applied mineral oil enhanced hormones and phenols content and hastened breaking bud dormancy in "Astrachan" apple trees, International Journal for Empirical Education and Research 1 (2) (2018a) 57-73.

[11] M.A. Seif El-Yazal et al., Changes in promoter and inhibitor substances during dormancy release in apple buds under foliar-applied dormancy-breaking agents, International Journal for Empirical Education and Research. 1 (4) (2018b)1-20.

[12] M.A. Seif El-Yazal et al., Metabolic changes in polyamines, phenylethylamine, and arginine during bud break in apple flower buds under foliar-applied dormancy-breaking, International Journal for Empirical Education and Research. 1 (2) (2018c) 1-18.

[13] M.A. Seif El-Yazal et al., Changes in metabolic processes during break dormancy in apple buds under foliar-applied garlic extract, International Journal for Empirical Education and Research. 1(4) (2018d) 36-58.

[14] J.M.S. Parra et al., Cold compensators in apple tree 'Golden Glory': development and production, Revista Mexicana Ciencias Agrícolas. 11(1) (2020) 69-82.

[15] M.A. Seif El-Yazal et al., Onion extract application effects on flowering behavior and yield, and a few chemical constituents of shoots throughout dormancy break in "Anna" apple trees, Journal of Horticulture and Plant Research. 7(2019)1-15.

[16] M.A. Seif El-Yazal andS.A. Seif El-Yazal, Impact of chilling requirements on metabolic changes in nitrogenous compounds in buds during and after dormancy releasing in early and late (Malus sylvestris, Mill) apple varieties, Horticult. Int.J. 3(5) (2019)230-238.

[17] R.V. Botelho and M.M.L. Muller, Evaluation of garlic extract on bud dormancy release of "Royal Gala" apple trees, Australian Journal of Experimental Agriculture. 47 (6): (2007) 738741. 
[18] L.E.Quintana, Aplicación de promotores de brotación en base a la actividad metabólica de las yemas en manzano Golden Delicious, Tesis de Maestría de la Facultad de Ciencias Agrotecnologicas Universidad Autónoma Chihuahua. (2006) 103 p.

[19] M.E.Morsi and M.A. seif El-Yazal, Effect of garlic and onion extract on bud break, growth, yield, berry quality and some chemical constituents of flam seedless and superior grapevines (Vitis vinifera L. ), Egypt. J. Hort. 35(1) (2008a) 1-28.

[20] M.E.Morsi and M.A. seif El-Yazal, Effect of potassium nitrate, garlic and onion extracts on bud break, growth, yield and some chemical constituents of apple (Malus sylvestris, Mill) trees, Fayoum J. Agric. Res. \& Dev. 22(1) (2008b) 82-93.

[21] M.M. Rady and M.A. Seif El-Yazal, Response of "Anna" apple dormant buds and carbohydrate metabolism during floral bud break to onion extract, Scientia Horticulturae. 155(2013) 78-84.

[22] M.M. Rady and M.A. Seif El-Yazal, Garlic extract as a novel strategy to hasten dormancy release in buds of 'Anna' apple trees, South African Journal of Botany. 92(2014) 105-111.

[23] M.A. Seif El-Yazal and M.M. Rady, Changes in nitrogen and polyamines during breaking bud dormancy in "Anna" apple trees with foliar application some compounds, Scientia Horticulturae. 136(2012) 75-80.

[24] M.A. Seif El-Yazal and M.M. Rady,Exogenous onion extract hastens bud break, positively alters enzyme activity, hormone, amino acids and phenol contents, and improves fruit quality in 'Anna' apple trees, Scientia Horticulturae. 169(2014) 154-160.

[25] M.A. Seif El-Yazal andS.A. Seif El-Yazal, Impact of foliar-applied dormancy-breaking agents on flowering behavior, yield, fruit quality and some chemical constituents of " Ein Shamer" apple trees, Innovare Journal of Agri. Sci. 9 (1) (2021) 16-21.

[26] A.A. El- Shewy et al., ffect of some dormancy breaking components on blooming, fruit set, yield, yield components and physical and chemical properties of fruits of some apple cultivars. A. Blooming and fruit set, Annals of Agric. Sci., Moshtohor. 37(4) (1999a) 2235 - 2246.

[27] A.A. El- Shewy et al.,Effect of some dormancy breaking components on blooming, fruit set, yield, yield components and physical and chemical properties of fruits of some apple cultivars. B-.Yield, yield components and physical and chemical properties of fruits, Annals of Agric. Sci., Moshtohor. 37(4) (1999b) 2247 - 2267.

[28] A.A. El- Shewy et al., Effect of some dormancy breaking components on leaves and fruits chemical composition of some apple cultivars. 1. Chemical composition of leaves, Annals of Agric. Sci., Moshtohor37(4). (1999c) 2269 - 2278.

[29] A.A. El- Shewy et al., Effect of some dormancy breaking components on chemical composition of leaves and buds of some apple cultivars. 11. Chemical composition of vegetative and generative buds, Annals of Agric. Sci., Moshtohor. 37(4) (1999d) 2279 - 2306.

[30] S.A.Wilde et al., Soil and Plant Analysis For Tree Culture, $3^{\text {rd }}$ Ed. Oxford IBLT Publishing Co., New Delhi.(1985) 9-100.

[31] A.R. Welburn and H. Lichtenthaler, Formula and program to determine total caroteniods and chlorophyll $\mathrm{a}$ and $\mathrm{b}$ of leaf extracts different solvents, In Advances in photosynthesis Research (Sybesma C.Ed.). II (1984) 9-12, Mortinus Njihoff Dr. W. Junk publishers, the Hague.

[32] D.Herbert et al., Determination of total carbohydrates, Methods in Microbian. 5 (B) (1971) 209-244.

[33] J. Jayarman, Laboratory Manual in Biochemistry, Wiley Eastern Limited New York. (1981) 61-73. 
[34] AOAC, Association of Analytical Chemist, Official methods of analysis of AOAC International. 17th edition. Gaithersburg, MD, USA, Associationof Analytical Communities2000.

[35] A.I. Page et al., A I, "Methods of Soil Analysis", Part II. Chemical and Microbiological Methods. $2^{\text {nd }}$ Ed. Amer. Soc. Agron., Madison, Wisconsin, USA (1982).

[36] K.A. Gomez and A.A. Gomez, Statistical Analysis Procedure of Agricultural Research. John Wiley and Sons, New York (1984) 25-30.

[37] F.B.Salisbury and C.W. Ross, The photosynthesis, transpiration compromise, In: Plant Physiology. (1992) 66 -92. Wadsworth Pub. Comp., California USA

[38] V. Rajagopal and I.M. Rao, Changes in the endogenous level of auxin and gibberellin like substances in the shoot apices of N- deficient tomato plant, Aust. J. Bot. 22(1974) $429-435$.

[39] D.J. Greenwood and J. Hunt, Effect of nitrogen fertilizer on the nitrate contents of field vegetables grown in Britain, J. Sci. Food Agric. 37(1986) 373 - 383.

[40] K.Mengel and E.A. Kirkby, Principal of plant nutrition, $.4^{\text {th }}$ Ed. International potash Institute. Pern, Switzerland. (1987) 687.

[41] I. Kuroi, Effects of calcium cyanamide on bud break of "Kyoho" grape, J. Japan Soc.,Hort. Sci. 54(1985) 301-306.

[42] Y.S. Yang et al., The effect of calcium cyanamide on bud break retranslocation of accumulated 14c- assimilates and changes of nitrogen in grapevines in Taiwan, Acta.Hort. 279(1990) 409-425.

[43] C.S. Miller and W.C. Hall, The fat of cyanamide in cotton, Agric. And Food Chemistry. 11(1963)222-225.

[44] J.H. Foott, The effect of hydrogen cyanamide on breaking endo-dormancy of mid-chilling apple, Acta. Hort.329(1987)268-270.

[45] V. Luna V. et al., Levels of endogenous gibberellins, abscisic acid, Indole 3 acetic acid and naringenin during dormancy of peach flower buds, Acta Hort. 329(1993)165 -267.

[46] S. Subha-drabandhu, Induction of bud break in apple trees that received insufficient chilling by hydrogen cyanamide, Acta Hort. 409(1995) 171-178.

[47] E.M.A. Nashaat, Bud break, yield, fruit quality and some endogenous compounds of flame seedless grape vines and sultani fig trees in relation of dormex spray, M. Sc. Thesis, Univ. of Alexandria. (1996).

[48] K.G.M. Skene, A comparison of the effects of cycocell and tipping on fruit set Vitis vinefra L. Aust. J. Bio. Sci. 22(1969)1305 - 1311.

[49] J. Tromp, Storage and mobilization of nitrogenous compounds in apple trees with special reference to arginine, In physiology of trees crops., Eds. L.C. Luckwill and C.V. cutting 14(1970) 3-59. Academic Press, Londone and New York.

[50] H.A. Boghdadi, Principles of fruit production. Dar El-Maerif, Cairo, Egypt, $3^{\text {rd }}$ ed. (1964) 663-667.

[51] C.D. Dame et al., The influence of ripeness on the organic acids, sugars and pectin of canned Bartlett pears, Fd. Techn. Champing. 10(1956) 23-33.

[52] S.S. Mann and B. Singh, Some aspects on development physiology of patharankh pear, Acta. Hort. 279 (1990) 155-158.

[53] L.W. Mapson, Vitamins in fruits. In The Biochemistry of fruits and their production, Vol. 1, Ac Hulme. Ed . Academic press. New York. (1970). 
[54] A.P. George et al., Factors affecting fruit quality of low chill stone fruit in subtropical Australia, Acta. Hort. 279(1990) 559-564.

[55] E.Z. Ahmed, Effect of Gibberellin, Cycocel, Calcium and Boron, fruit size and position within tree canopy on quality and mineral content of Anna apple fruits during storage, $\mathrm{Ph}$. D. Thesis, Alexandria Univ. (1995).

[56] B.M. Gangwar, Biochemical studies on growth and ripening of guava, Indian Food Packer. 26(1972) 13-15. 